\title{
TBL2 wt Allele
}

National Cancer Institute

\section{Source}

National Cancer Institute. TBL2 wt Allele. NCI Thesaurus. Code C104552.

Human TBL2 wild-type allele is located in the vicinity of $7 q 11.23$ and is approximately 10 $\mathrm{kb}$ in length. This allele, which encodes transducin beta-like protein 2 , may play a role in signal transduction. In Williams-Beuren syndrome, the chromosomal region this gene is located in is deleted. 